\title{
SISTEM PAKAR BERBASIS LOGIKA FUZZY UNTUK DETEKSI LEVEL PENYAKIT SCABIES
}

\section{FUZZY BASED EXPERT SYSTEM FOR DETECTION OF SCABIES DISEASE LEVEL}

\author{
Muhamad Safi' ${ }^{1}$ \\ Hanny Haryanto ${ }^{2}$ \\ Jurusan Teknik Informatika Universitas Dian Nuswantoro Semarang ${ }^{1,2}$ \\ e-mail: 666xavii@gmail.com, hanny.haryanto@dsn.dinus.ac.id \\ Diterima: 8 Juni 2017/ Disetujui : 15 Juni 2017
}

\begin{abstract}
Scabies is a skin disease that is easily transmitted, either through direct contact or through intermediaries such as clothes, bed sheet, and water. The disease causes itching on the body, especially at night. Transmission of the scabies disease is very fast and can develop into an outbreak in a community. Obstacles that occur in the treatment of this disease is not all people with the disease could check it for a variety of reasons, such as too busy with work and economic limitations. This research using fuzzy Tsukamoto to develop an expert system for the detection of scabiesdisease. The use of expert systems is very important because it can be a tool to substitute the expert, the expert system is easy to use, and can make decisions in a short time. Scabies disease diagnosis process carried out by way of input symptoms that suffered by patients. Symptoms that are used as input is a scratchy, itchy location, number of lesions or spots, and an extensive history of itching or the number of infected person. The outcome of this process is the level of scabies from mild to severe.
\end{abstract}

Keywords : Expert system, tsukamoto fuzzy, scabies, artificial intelligence, human.

\begin{abstract}
ABSTRAK
Scabies adalah sejenis penyakit kulit yang mudah menular, baik melalui kontak langsung ataupun melalui perantara seperti baju, sprai, dan air. Penyakit ini menyebabkan gatal pada tubuh, terutama pada saat malam hari. Penularan penyakit scabies ini sangat cepat dan dapat berkembang menjadi wabah di sebuah kelompok masyarakat. Kendala yang terjadi dalam penanganan penyakit ini adalah tidak semua penderita scabies dapat memeriksakan penyakitnya karena berbagai alasan, seperti terlalu sibuk dengan pekerjaannya maupun keterbatasan ekonomi Dalam penelitian ini menggunakan metode fuzzy tsukamoto untuk merancang sistem pakar untuk deteksi penyakit scabies. Penggunaan sistem pakar sangat penting karena dapat menjadi alat bantu sementara sebagai pengganti ahli, sistem pakar mudah digunakan oleh orang awam, dan dapat mengambil keputusan dalam waktu yang singkat. Proses diagnosa penyakit scabies dilakukan dengan cara menginputkan gejala - gejala yang diderita oleh pasien. Gejala yang digunakan sebagai inputadalah waktu gatal, lokasi gatal, banyaknya lesi atau bintik - bintik, dan banyaknya riwayat gatal atau orang sekitar yang tertular. Hasil dari proses ini adalah level scabies dari tingkat yang ringan sampai berat.
\end{abstract}

Kata kunci : Sistem pakar, fuzzy tsukamoto, scabies, kecerdasan buatan, manusia. 


\section{PENDAHULUAN}

Penyakit kulit merupakan penyakit atau infeksi yang umum terjadi pada orang - orang disegala usia. Gangguan kulit ini terjadi karena beberapa faktor. Faktor tersebut meliputi kebiasaan hidup yang kurang sehat, iklim, lingkungan, tempat tinggal, dan lainnya[1].Ada berbagai macam penyakit kulit yang dapat dialami oleh semua manusia di dunia ini, salah satunya adalah penyakit Scabies. Scabiesmerupakan penyakit kulit yang disebabkan oleh tungau atau kutu yang bernama Sarcoptes Scabiei.Ciri kutu scabies ini antara lain berukuran 0,3-0,4 mm, berbentuk oval, cembung, dan datar pada sisi perutnya. Scabies dapat menular baik melalui kontak langsung ataupun melalui perantara seperti baju, sprai, dan air. Oleh karena itu, penderitanya harus menjaga betul- betul kebersihannya dan harus sering membersihkan juga tempat tidur, sprainya disetrika, pakaiannya direndam air panas[2].

Kebanyakan dari penderitanya lebih tergantung kepada dokter ahli untuk mengetahui level penyakit scabies yang mereka alami. Akan tetapi tidak semua penderita scabies dapat memeriksakan penyakitnya karena berbagai alasan, seperti terlalu sibuk dengan pekerjaannya maupun keterbatasan ekonomi[3].Penggunaan sistem pakar sangat penting karena dapat menjadi alat bantu sementara sebagai pengganti ahli, sistem pakar mudah digunakan oleh orang awam, dan dapat mengambil keputusan dalam waktu yang singkat[4]. Maka dari itu untuk membantu penderita scabies mendeteksi levelnya dibuatlah sistem kecerdasan buatan yang dapat mendeteksi level penyakit scabieskarena salah satu bagian utama dalam kecerdasan buatan adalah adanya mesin inferensi yaitu kemampuan untuk mengambil sebuah kesimpulan[5].

Beberapa penelitian terdahulu dengan penerapan Fuzzy Tsukamoto yang relevan pada penelitian ini adalah sebagai berikut.Penelitian berjudul "Sistem Penunjang Keputusan Kelayakan Pemberian Pinjaman Dengan Metode Fuzzy Tsukamoto" yang ditulis oleh Tri Murti, Leon Andretti Abdillah, dan Muhammad Sobri. Penelitian ini bertujuan untuk membantu menyelesaikan masalah yang terjadi pada PT. Triprima Finance yang merupakan perusahaan di bidang jasa peminjaman dengan jaminan BPKB. Masalah yang terjadi di sini adalah lamanya waktu untuk proses persetujuan dari kepala manajer untuk mempertimbangkan pinjaman bagi nasabahnya karena proses pengambilan keputusannya masih menggunakan analisis secara manual. Maka dari itu perlu dikembangkannya sistem yang baru dengan menggunakan metode Fuzzy Tsukamoto dan diharapkan akan mempermudah proses pengambilan keputusan peminjaman [6].Penelitian selanjutnya berjudul "Metode Logika Fuzzy Tsukamoto Dalam Sistem Pengambilan Keputusan Penerimaan Beasiswa" yang ditulis oleh Maryaningsih, Siswanto, dan Meterjon. Penelitian ini bertujuan untuk membantu pengambilan keputusan untuk menentukan penerimaan beasiswa karena sering terjadi masalah pada subyektifitas, dimana kemampuan dan nilai dari siswa tersebut tidak jauh berbeda, maka dari itu perlu dibangun sistem penunjang untuk menentukan siswa yang berhak mendapatkan beasiswa. Sistem didukung dengan metode Fuzzy Tsukamoto yang dibuat berdasarkan kriteria - kriteria yang telah ditentukan oleh pihak donator. Software ini dibuat menggunakan Microsoft Access 2007 dan Microsoft Visual Basic 6.0. dengan aplikasi tersebut dapat membantu dalam penyaringan beasiswa dengan tepat. Hasil dari sistem ini berupa bobot penilaian siswa merupakan rekomendasi dalam keputusan penerimaan beasiswa [7]. Penelitian berjudul "Implementasi Metode Fuzzy Tsukamoto Pada Penentuan Harga Jual Barang Dalam Konsep Fuzzy Logic" yang ditulis oleh Rizky Amelia. Bagi sebuah perusahaan, penentuan harga jual barang merupakan hal yang sangat penting sebelum melakukan proses produksi. Maka dari itu dibutuhkan sistem yang dapat membantu menyelesaikan masalah tersebut. Metode yang digunakan adalah Fuzzy Tsukamoto yang menerapkan rata - rata terbobot pada penghitungan harga jual barang. Hasil dari sistem ini dapat membantu distributor dalam membuat keputusan saat menentukan harga jual barang [8].Penelitian berjudul "Comparative Analysis Of Mamdani, Sugeno, And Tsukamoto Method Of Fuzzy Inference System For Air Conditioner Energy Saving” yang ditulis oleh Aep Saepullah dan Romi Satria Wahono. Penelitian ini bertujuan untuk membandingkan metode mana yang lebih baik dalam hal pengurangan terhadap energi listrik dari AC antara Fuzzy Mamdani, Sugeno, dan Tsukamoto. Variabel masukannya adalah suhu kamar dan kelembaban dan kecepatan kompresor sebagai variabel keluaran. Percobaan dilakukan dengan menggunakan masukan dari suhu kamar $11^{\circ} \mathrm{C}$ dan $21 \%$ kelembaban, suhu kamar $14^{\circ} \mathrm{C}$ dan $41 \%$ kelembaban, suhu kamar $27^{\circ} \mathrm{C}$ dan $44 \%$ kelembaban, suhu kamar $33^{\circ} \mathrm{C}$ dan $68 \%$ kelembaban. 
Hasilnya adalah Fuzzy Tsukamoto sebagai metode terbaik dalam hal pengurangan dan efisiensi konsumsi energy listrik dengan rata - rata pencapaian 74,2775\% [9].

Dari berbagai pembahasan yang telah disampaikan pada latar belakang diatas, permasalahan yang terjadi adalah tidak semua penderita scabies dapat memeriksakan penyakitnya dengan berbagai alasan seperti kurangnya pengetahuan, terlalu sibuk bekerja, keterbatasan ekonomi, dan sistem deteksi level penyakit adalah salah satu solusinya. Oleh sebab itu, tujuan dari penelitian ini adalah merancang sistem cerdas menggunakan Fuzzy Tsukamoto untuk diagnosa level penyakit scabies..

\section{METODE PENELITIAN}

Metode yang digunakan untuk mendeteksi level penyakit scabies adalah Logika Fuzzy karena dapat dipakai untuk mengatasi hal yang tidak pasti pada masalah yang mempunyai banyak jawaban [10]. Logika Fuzzy yang digunakan adalahFuzzy Tsukamoto.Tahapan - tahapan dari metode Fuzzy Tsukamoto adalah

1. Fuzzyfikasi

2. Membentuk basis pengetahuan fuzzy (alur IF...THEN)

3. Inferensi

Penggunaan implikasi MIN untuk mendapat nilai a-predikat dari tiap rule (a1,a2, ..an)

4. Defuzzyfikasi

Misalnya menggunakan metode rata - rata

$z^{*}=\frac{2 a_{i} z_{1}}{\sum a_{i}}$

Maka hasilnya adalah

$$
z=\frac{\alpha_{1} z_{1}+\alpha_{2} z_{2}}{\alpha_{1}+\alpha_{2}}
$$

Tabel 1. Rules Gejala Penyakit Scabies dan Hasil

\begin{tabular}{|c|c|c|c|c|c|}
\hline \multirow{2}{*}{ No } & \multicolumn{4}{|c|}{ IF } & \multirow{2}{*}{ THEN } \\
\cline { 2 - 5 } & WG & LG & LESI & RG & \\
\hline 1 & PagiSiang & Sedikit & Sedikit & Sedikit & Ringan \\
\hline 2 & PagiSiang & Banyak & Sedikit & Sedikit & Ringan \\
\hline 3 & PagiSiang & Sedikit & Banyak & Sedikit & Ringan \\
\hline 4 & PagiSiang & Banyak & Banyak & Sedikit & Berat \\
\hline 5 & PagiSiang & Sedikit & Sedikit & Banyak & Ringan \\
\hline 6 & PagiSiang & Banyak & Sedikit & Banyak & Berat \\
\hline 7 & PagiSiang & Sedikit & Banyak & Banyak & Berat \\
\hline 8 & PagiSiang & Banyak & Banyak & Banyak & Berat \\
\hline 9 & SoreMalam & Sedikit & Sedikit & Sedikit & Ringan \\
\hline 10 & SoreMalam & Banyak & Sedikit & Sedikit & Berat \\
\hline 11 & SoreMalam & Sedikit & Banyak & Sedikit & Berat \\
\hline 12 & SoreMalam & Banyak & Banyak & Sedikit & Berat \\
\hline 13 & SoreMalam & Sedikit & Sedikit & Banyak & Berat \\
\hline 14 & SoreMalam & Banyak & Sedikit & Banyak & Berat \\
\hline 15 & SoreMalam & Sedikit & Banyak & Banyak & Berat \\
\hline 16 & SoreMalam & Banyak & Banyak & Banyak & Berat \\
\hline
\end{tabular}

Cara penularan dari penyakit scabies ini ada 2, diantaranya adalah :

1. Secara langsung, yaitu lewat sentuhan langsung melalui kulit.

2. Secara tidak langsung, yaitu lewat handuk, pakaian, dan tempat tidur yang digunakan bersama sama. 
Berikut ini adalah gejala dari penyakit scabies :

1. Munculnya terowongan kecil pada kulit (tempat dimana kutu berada)

2. Gatal pada malam hari.

3. Gatal di bagian lipatan - lipatan tubuh, sperti ketiak, selangkangan, pantat.

4. Gatal pada payudara, garis bra (wanita).

5. Gatal pada alat kelamin (pria).

6. Pada bayi, gatal dapat menyerang seluruh tubuh.

Sistem pakar terdiri dari dua bagian utama, yaitu lingkungan pengembang (defelopment environment) dan lingkungan konsultasi (consultation environment). Defelopment environment dipakai oleh pengembang dari sistem pakar untuk membangun komponen-komponen dan mengenalkan suatu pengetahuan kepada knowledge base. Consultation environment dipakai oleh pengguna untuk mendapatkan informasi dan pengetahuan tentang pakar [4].

Komponen-komponen yang ada dalam kedua bagian tersebut dapat dilihat pada gambar 2.1 berikut ini [8]:

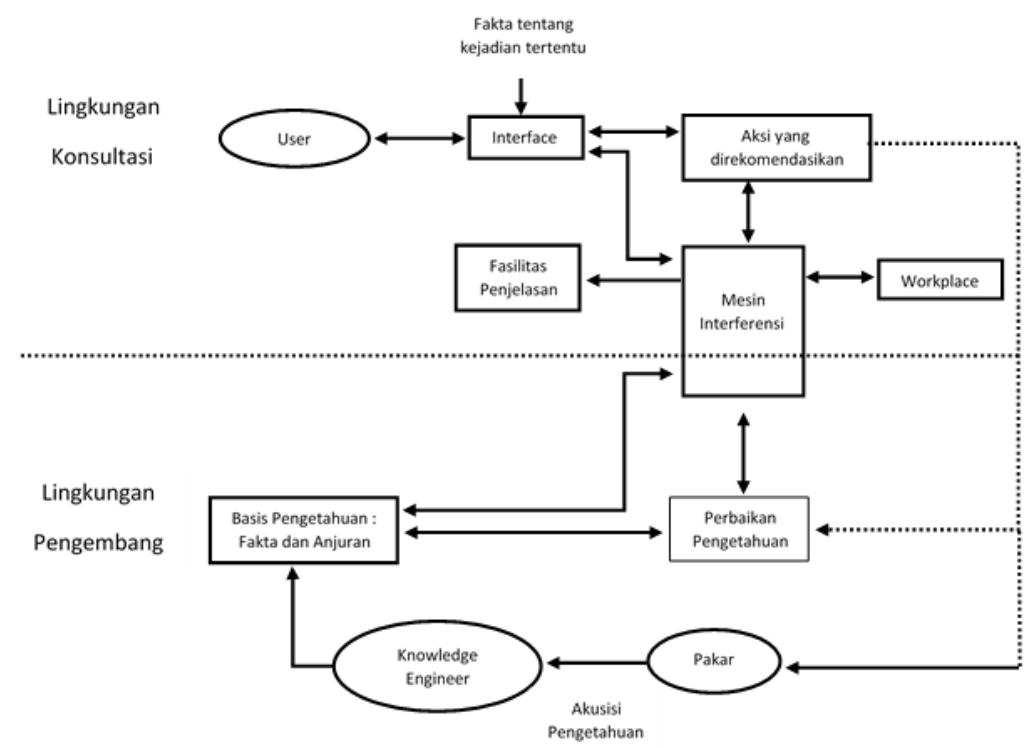

Gambar 1. Komponen-komponen yang penting dalam sistem pakar[5].

Penjelasan ringkas mengenai komponen-komponen yang membentuk sistem pakar adalah sebagai berikut [5]:

1. User Interface

User Interface atau Pengguna Antar Muka digunakan untuk komunikasi antara pengguna dengan sistem pakar.

2. Knowledge Base

Knowledge Base atau Basis Pengetahuan mengandung informasi mengenai pengetahuanpengetahuan yang dibutuhkan untuk pemahaman, formulasi, dan penyelesaian masalah.

3. Knowledge Asquisition

Knowledge Asquisition atau Akusisi Pengetahuan adalah akumulasi, transformasi dan transfer keahlian dari pakar ke dalam program komputer untuk menyelesaikan masalah.

4. Inference Engine

Inference Engine atau Mesin Inferensi adalah bagian yang mengandung mekanisme untuk menganalisa suatu masalah tertentu dengan cara mengolah data dari pola-pola penalaran sistem yang digunakan pakar untuk mencari jawaban atau kesimpulan terbaik.

5. Workplace

Workplace merupakan area yang ada didalam memori yang berfungsi untuk merekam kejadian yang sedang berlangsung untuk mengetahui rencana, agenda, dan solusi untuk mencapai kesimpulan yang terbaik. 
6. Fasilitas Penjelasan

Digunakan untuk meningkatkan kemampuan sistem pakar dengan cara melacak respon dan memberi penjelasan tentang sistem pakar secara interaktif dengan memberi pertanyaan kepada pengguna.

7. Perbaikan Pengetahuan

Digunakan untuk mengevaluasi kinerja dari sistem pakar untuk melihat perkembangan pengetahuan-pengetahuan yang ada masih cocok untuk masa mendatang.

8. User

Seorang user atau pengguna pada umumnya bukanlah seorang pakar (Non-expert) yang membutuhkan solusi, saran, atau pelatihan dari berbagai masalah yang ada.

\section{HASIL DAN PEMBAHASAN}

\subsection{Data yang digunakan}

Data yang digunakan untuk perhitungan fuzzy tsukamoto adalah data pasiendengan gejala dari penyakit scabies.

Tabel 2. Data Pasien Scabies

\begin{tabular}{|c|c|c|c|c|c|}
\hline \multirow[t]{2}{*}{ No } & \multirow[t]{2}{*}{ Inisial } & \multicolumn{4}{|c|}{ IF } \\
\hline & & WG & LG & LESI & $\mathrm{RG}$ \\
\hline 1 & $\mathrm{M}$ & Pagisiang (7) & $\begin{array}{l}\text { Banyak } \\
\text { (5) }\end{array}$ & $\begin{array}{l}\text { Banyak } \\
\text { (11) }\end{array}$ & $\begin{array}{l}\text { Sedikit } \\
\text { (1) }\end{array}$ \\
\hline 2 & NI & $\begin{array}{l}\text { Pagisiang } \\
\text { (13) }\end{array}$ & $\begin{array}{l}\text { Sedikit } \\
\text { (2) }\end{array}$ & $\begin{array}{c}\text { Banyak } \\
\text { (10) }\end{array}$ & $\begin{array}{l}\text { Sedikit } \\
\text { (1) }\end{array}$ \\
\hline 3 & MT & $\begin{array}{l}\text { Soremalam } \\
\text { (17) }\end{array}$ & $\begin{array}{c}\text { Banyak } \\
(4)\end{array}$ & $\begin{array}{l}\text { Sedikit } \\
(5)\end{array}$ & $\begin{array}{c}\text { Banyak } \\
(3)\end{array}$ \\
\hline 4 & MH & $\begin{array}{l}\text { Pagisiang } \\
\text { (10) }\end{array}$ & $\begin{array}{l}\text { Sedikit } \\
\text { (2) }\end{array}$ & $\begin{array}{l}\text { Sedikit } \\
\text { (6) }\end{array}$ & $\begin{array}{l}\text { Sedikit } \\
\text { (1) }\end{array}$ \\
\hline 5 & ST & $\begin{array}{l}\text { Soremalam } \\
\text { (19) }\end{array}$ & $\begin{array}{l}\text { Sedikit } \\
\text { (2) }\end{array}$ & $\begin{array}{c}\text { Banyak } \\
\text { (12) }\end{array}$ & $\begin{array}{c}\text { Banyak } \\
(2)\end{array}$ \\
\hline 6 & MS & $\begin{array}{l}\text { Soremalam } \\
\text { (19) }\end{array}$ & $\begin{array}{l}\text { Banyak } \\
\text { (5) }\end{array}$ & $\begin{array}{l}\text { Sedikit } \\
\text { (3) }\end{array}$ & $\begin{array}{l}\text { Sedikit } \\
\text { (1) }\end{array}$ \\
\hline 7 & $\mathrm{R}$ & $\begin{array}{l}\text { Soremalam } \\
\text { (18) }\end{array}$ & $\begin{array}{c}\text { Banyak } \\
\text { (4) }\end{array}$ & $\begin{array}{c}\text { Banyak } \\
\text { (9) }\end{array}$ & $\begin{array}{c}\text { Banyak } \\
\text { (2) }\end{array}$ \\
\hline 8 & $\mathrm{Y}$ & $\begin{array}{l}\text { Soremalam } \\
\text { (23) }\end{array}$ & $\begin{array}{l}\text { Sedikit } \\
\text { (3) }\end{array}$ & $\begin{array}{c}\text { Banyak } \\
\text { (14) }\end{array}$ & $\begin{array}{c}\text { Banyak } \\
\text { (3) }\end{array}$ \\
\hline 9 & $\mathrm{I}$ & Pagisiang (8) & $\begin{array}{c}\text { Banyak } \\
\text { (4) }\end{array}$ & $\begin{array}{l}\text { Sedikit } \\
(5)\end{array}$ & $\begin{array}{l}\text { Sedikit } \\
\text { (1) }\end{array}$ \\
\hline 10 & HR & $\begin{array}{l}\text { Soremalam } \\
\text { (22) }\end{array}$ & $\begin{array}{c}\text { Banyak } \\
(6)\end{array}$ & $\begin{array}{l}\text { Sedikit } \\
\text { (3) }\end{array}$ & $\begin{array}{l}\text { Sedikit } \\
\text { (1) }\end{array}$ \\
\hline 11 & K & Pagisiang (7) & $\begin{array}{l}\text { Sedikit } \\
\text { (2) }\end{array}$ & $\begin{array}{l}\text { Sedikit } \\
(5)\end{array}$ & $\begin{array}{c}\text { Sedikit } \\
(1)\end{array}$ \\
\hline 12 & NA & Pagisiang (7) & $\begin{array}{l}\text { Sedikit } \\
\text { (1) }\end{array}$ & $\begin{array}{c}\text { Banyak } \\
(6)\end{array}$ & $\begin{array}{c}\text { Banyak } \\
\text { (2) }\end{array}$ \\
\hline 13 & $\mathrm{M}$ & $\begin{array}{l}\text { Soremalam } \\
\text { (21) }\end{array}$ & $\begin{array}{l}\text { Sedikit } \\
\text { (1) }\end{array}$ & $\begin{array}{l}\text { Sedikit } \\
\text { (3) }\end{array}$ & $\begin{array}{l}\text { Sedikit } \\
(2)\end{array}$ \\
\hline 14 & $\mathrm{~J}$ & Pagisiang (9) & $\begin{array}{c}\text { Banyak } \\
\text { (4) }\end{array}$ & $\begin{array}{l}\text { Sedikit } \\
(6)\end{array}$ & $\begin{array}{c}\text { Banyak } \\
\text { (3) }\end{array}$ \\
\hline 15 & $\mathrm{C}$ & $\begin{array}{l}\text { Soremalam } \\
\text { (15) }\end{array}$ & $\begin{array}{l}\text { Sedikit } \\
\text { (2) }\end{array}$ & $\begin{array}{c}\text { Banyak } \\
\text { (8) }\end{array}$ & $\begin{array}{l}\text { Sedikit } \\
\text { (1) }\end{array}$ \\
\hline
\end{tabular}




\begin{tabular}{|c|c|c|c|c|c|}
\hline 16 & PNA & Pagisiang (2) & $\begin{array}{c}\text { Banyak } \\
(6)\end{array}$ & $\begin{array}{c}\text { Sedikit } \\
(7)\end{array}$ & $\begin{array}{c}\text { Banyak } \\
(4)\end{array}$ \\
\hline 17 & DC & $\begin{array}{c}\text { Soremalam } \\
(19)\end{array}$ & $\begin{array}{c}\text { Banyak } \\
(6)\end{array}$ & $\begin{array}{c}\text { Banyak } \\
(3)\end{array}$ & $\begin{array}{c}\text { Banyak } \\
(4)\end{array}$ \\
\hline 18 & D & $\begin{array}{c}\text { Soremalam } \\
(19)\end{array}$ & $\begin{array}{c}\text { Sedikit } \\
(3)\end{array}$ & $\begin{array}{c}\text { Sedikit } \\
(2)\end{array}$ & $\begin{array}{c}\text { Banyak } \\
(2)\end{array}$ \\
\hline 19 & H & $\begin{array}{c}\text { Soremalam } \\
(20)\end{array}$ & $\begin{array}{c}\text { Banyak } \\
(5)\end{array}$ & $\begin{array}{c}\text { Sedikit } \\
(3)\end{array}$ & $\begin{array}{c}\text { Banyak } \\
(4)\end{array}$ \\
\hline 20 & ES & $\begin{array}{c}\text { Soremalam } \\
(23)\end{array}$ & $\begin{array}{c}\text { Banyak } \\
(3)\end{array}$ & $\begin{array}{c}\text { Banyak } \\
(5)\end{array}$ & $\begin{array}{c}\text { Sedikit } \\
(1)\end{array}$ \\
\hline
\end{tabular}

\subsection{Proses Perhitungan}

Contoh soal, seorang pasien berinisial $\mathrm{R}$ menderita penyakit scabies dengan gejala waktu gatal kira - kira pukul 23.00, lokasi gatal 5, jumlah lesi 8, dan riwayat keluarga yang tertular 3 .

Diketahui :

Waktu Gatal : $: 23$

Lokasi Gatal $\quad: 5$

Jumlah Lesi $\quad: 8$

Riwayat Gatal $\quad: 3$

Waktu Gatal (23)

$\mu$ SoreMalam [23] $\quad=1$

Lokasi Gatal (5)

$\mu$ Banyak [5] $\quad=1$

Jumlah Lesi (8)

$\mu$ Sedikit $[8] \quad=(10-8) / 5$

$=2 / 5$

$=0,4$

$\mu$ Banyak $[8] \quad=(8-5) / 5$

$=3 / 5$

$=0,6$

Riwayat Gatal (3)

$\mu$ Banyak [3] $\quad=1$

Setelah proses fuzzyfikasi, tahap selanjutnya adalah menentukan $\alpha$.Nilai $\alpha$ didapatkan dari nilai min semua atribut pada rule dari perhitungan sebelumnya. Berikut adalah contohnya :

$\mathrm{R}$ [14] Soremalam [1] \& Banyak [1] \& Sedikit [0,4] \& Banyak [1] THEN Berat [0,4]

$\alpha=0,4$

$\mathrm{R}$ [16] Soremalam [1] \& Banyak [1] \& Banyak [0,6] \& Banyak [1] THEN Berat [0,6] $\alpha=0,6$ 
Setelah semua nilai $\alpha$ diketahui, maka selanjutnya adalah penghitungan nilai Z. penghitungan nilai $\mathrm{Z}$ dilakukan berdasarkan nilai $\alpha$ dan rule yang telah ditentukan. Penghitungan tabel diatas dengan cara mengabaikan nilai $\alpha=0$ dan yang mempunyai nilai bukan 0 adalah R14 dan R16.

$\frac{z 14-2}{3-2}=0,4$
$\frac{z 14-2}{1}=0,4$

[R14] IF SoreMalam AND LG Banyak AND LESI Sedikit AND RG Banyak THEN Berat

$$
\begin{aligned}
& z 14-2=0,4 \\
& z 14=2,4
\end{aligned}
$$

[R16] IF SoreMalam AND LG Banyak AND LESI Banyak AND RG Banyak THEN Berat

$$
\begin{aligned}
& \frac{z 16-2}{3-2}=0,6 \\
& \frac{z 16-2}{1}=0,6 \\
& z 16-2=0,6 \\
& z 16=2,6
\end{aligned}
$$

Langkah terakhir adalah defuzzyfikasi. Setelah menentukan nilai $\alpha$ dan $\mathrm{Z}$ maka dilakukan proses defuzzyfikasi seperti berikut :

$$
\begin{aligned}
& z=\frac{a 14 * z 14+a 16 * z 16}{a 14+a 16} \\
& z=\frac{0,4 * 2,4+0,6 * 2,6}{0,4+0,6} \\
& z=\frac{0,96+1,56}{1} \\
& z=2,52
\end{aligned}
$$

Jadi pasien tersebut masuk pada kategori level scabies berat, karena hasil dari perhitungan menunjukkan nilai 2,52 yang masuk pada kategori level scabies berat.

\subsection{Antarmuka Sistem}

Berikut iniakan dipaparkan antarmuka sistem yang telah diimplementasikan ke dalam sistem.

\subsubsection{Antarmuka Halaman Utama}

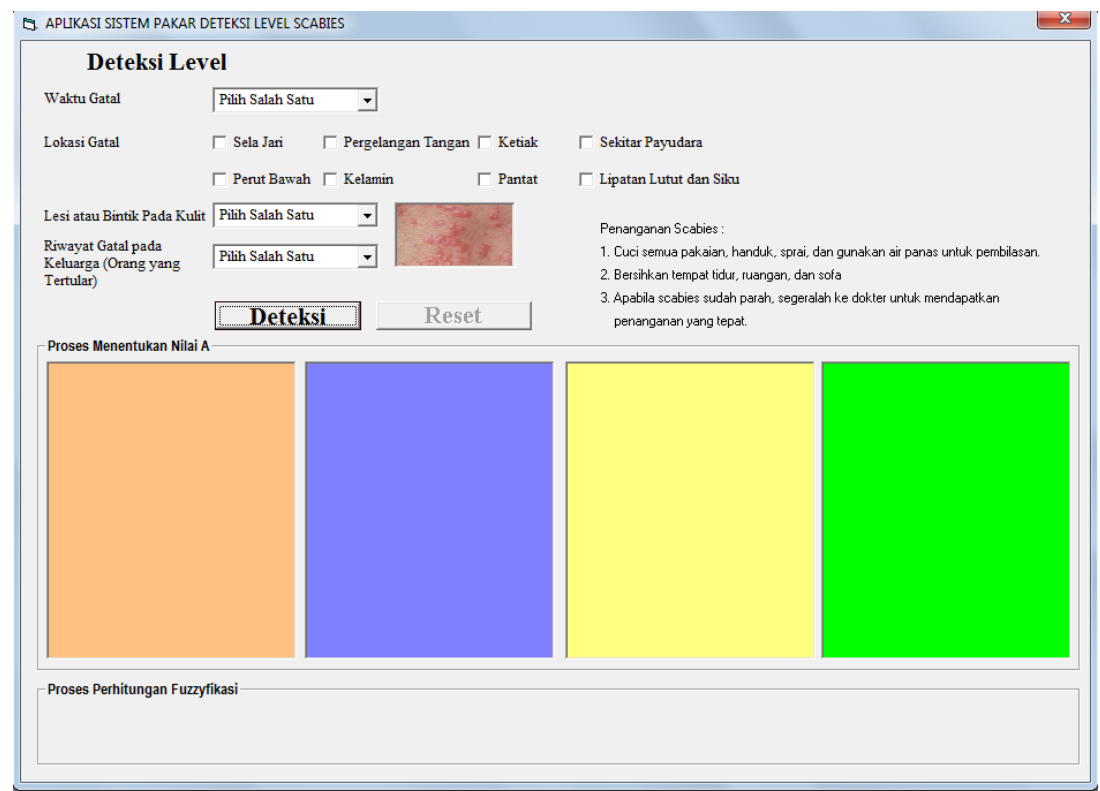

Gambar 2. Halaman Utama 
Tampilan di atas adalah tampilan utama dari aplikasi deteksi level penyakit scabies. Ada macam - macam menu diantaranya adalah waktu gatal, lokasi gatal, banyaknya lesi atau bintik - bintik, dan riwayat gatal atau orang yang tertular.

\subsubsection{Antarmuka Menu Waktu Gatal}

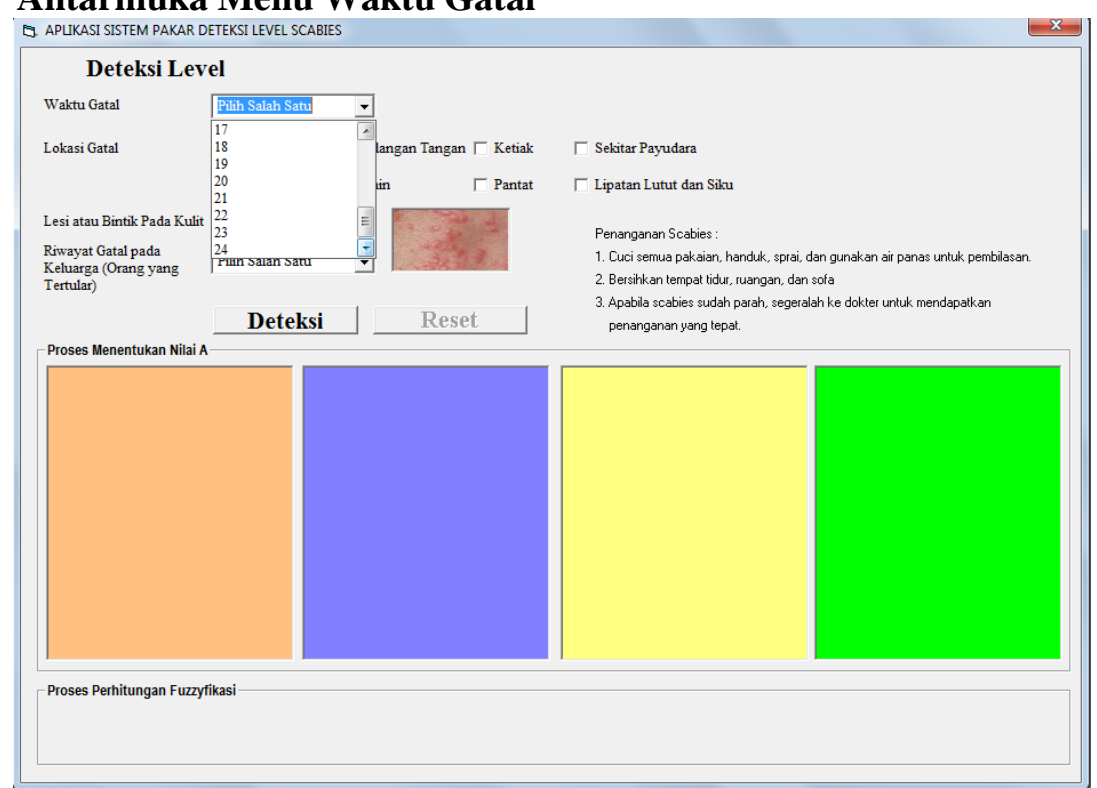

Gambar 3. Menu Waktu Gatal

Tampilan di atas merupakan menu waktu gatal, pada menu waktu gatal terdapat pilihan angka dari 1 sampai 24 yang menunjukkan waktu atau jam. Dimana pukul 01.00 sampai pukul 16.00 masuk dalam gejala pagisiang dan pukul 14.00 sampai pukul 24.00 masuk dalam gejala soremalam.

\subsubsection{Antarmuka Menu Lokasi Gatal}

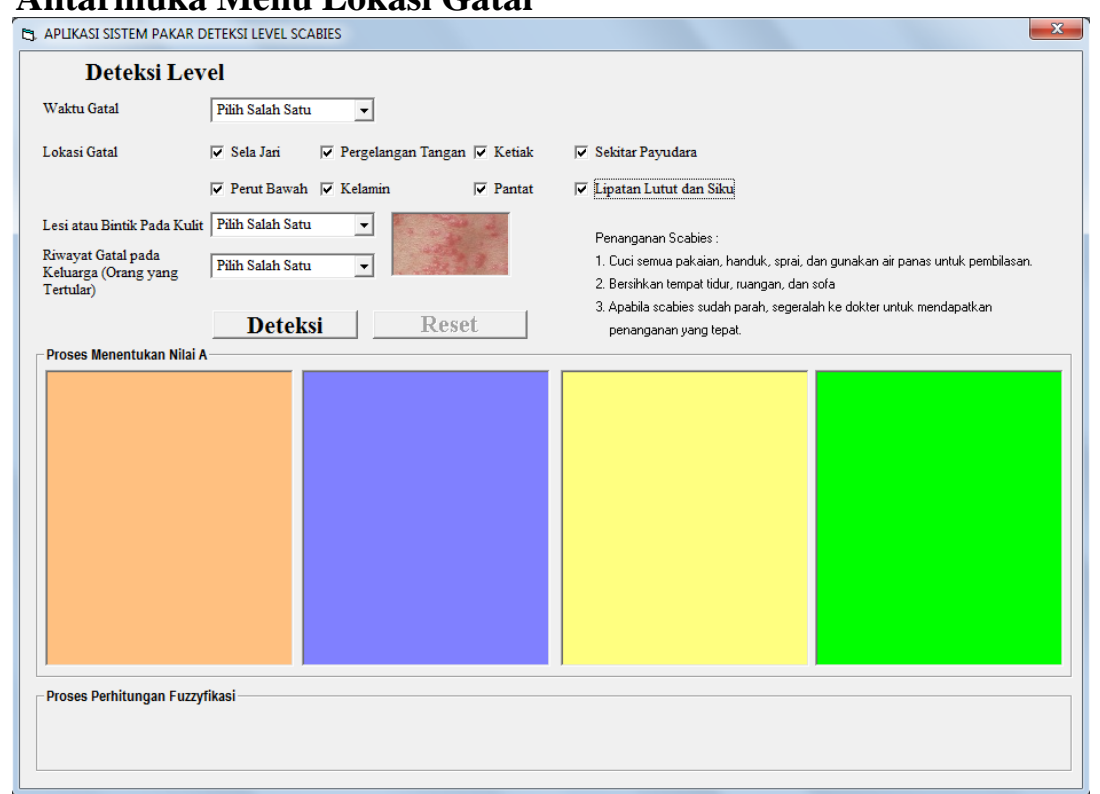

Gambar 4. Menu Lokasi Gatal

Pada menu lokasi gatal terdapat terdapat pilihan yang bisa di centang sesuai dengan lokasi gatal yang diderita oleh pasien scabies. Adapun pilihannya adalah sela jari, pergelangan tangan, ketiak, sekitar payudara, perut bawah, kelamin, pantat, lipatan lutut 
dan siku.Dimana 1 sampai 4 menunjukkan pada kategori lokasi gatal sedikit dan 2 sampai 8 menunjukkan lokasi gatal banyak.

\subsubsection{Antarmuka Menu Banyaknya Bintik - Bintik}

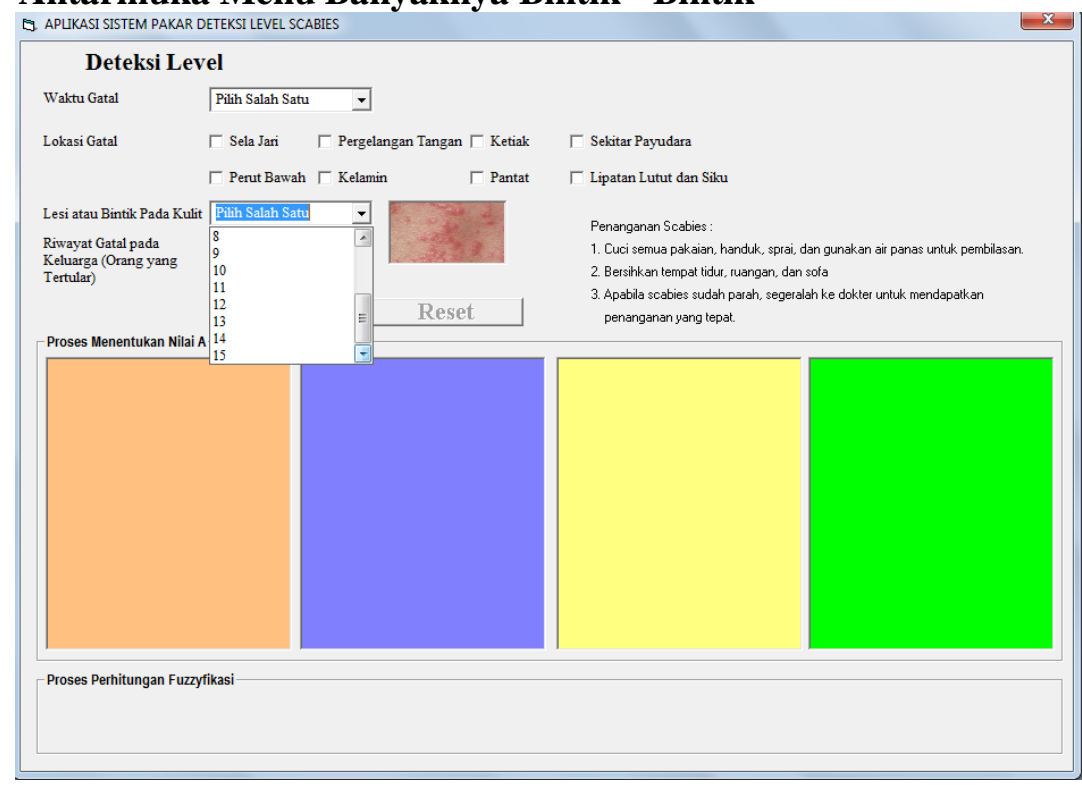

Gambar 5. Menu Banyaknya Bintik - Bintik

Tampilan di atas adalah tampilan dari menu lesi atau bintik - bintik, ada banyak pilihan angka mulai dari 1 sampai 15, user memilih angka sesuai dengan banyaknya bintik bintik yang ada pada lokasi gatal, apabila bintik - bintiknya melebihi 15, maka user tetap memilih 15. Angka 1 sampai 10 menunjukkan jumlah lesi sedikit dan 5 sampai 15 menunjukkan jumlah lesi banyak.

\subsubsection{Antarmuka Banyaknya Riwayat Gatal}

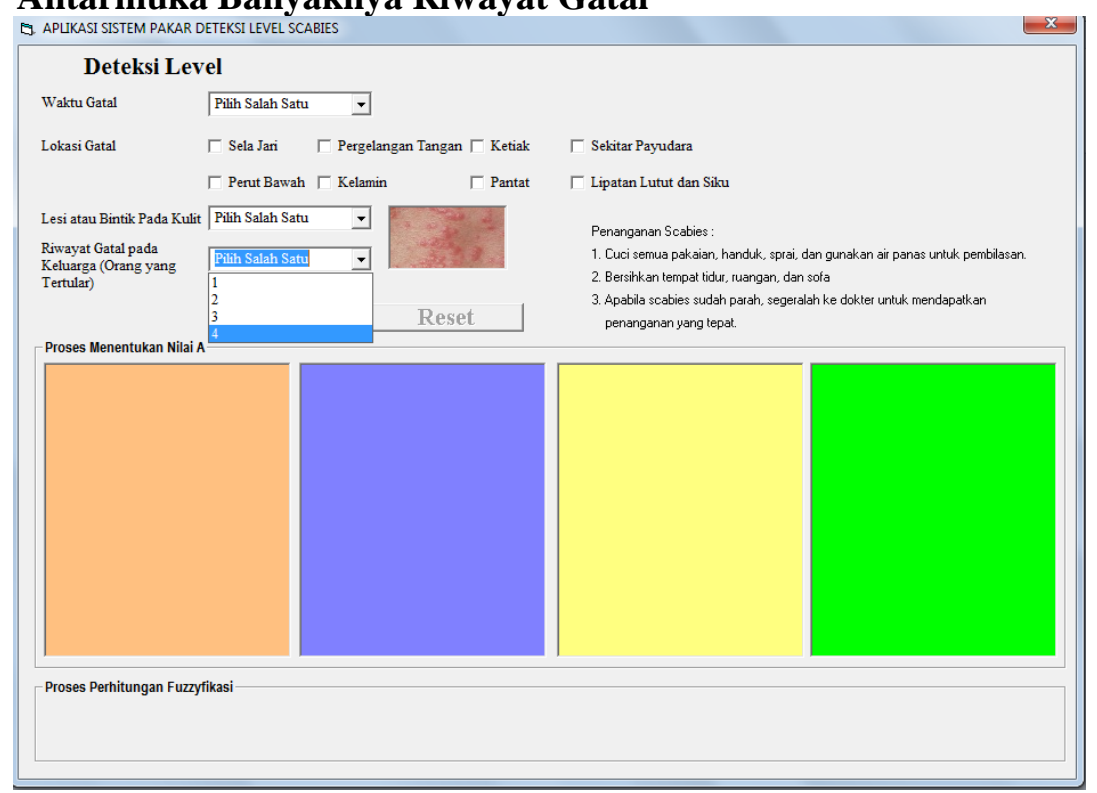

Gambar 6. Banyaknya Riwayat Gatal

Gambar diatas merupakan tampilan dari menu riwayat gatal atau orang yang tertular, ada pilihan mulai dari angka 1 sampai 4 yang menunjukkan banyaknya orang yang tertular, jika yang tertular melebihi 4 orang, maka tetap memilih 4 . 


\subsubsection{Antarmuka Hasil Ringan}

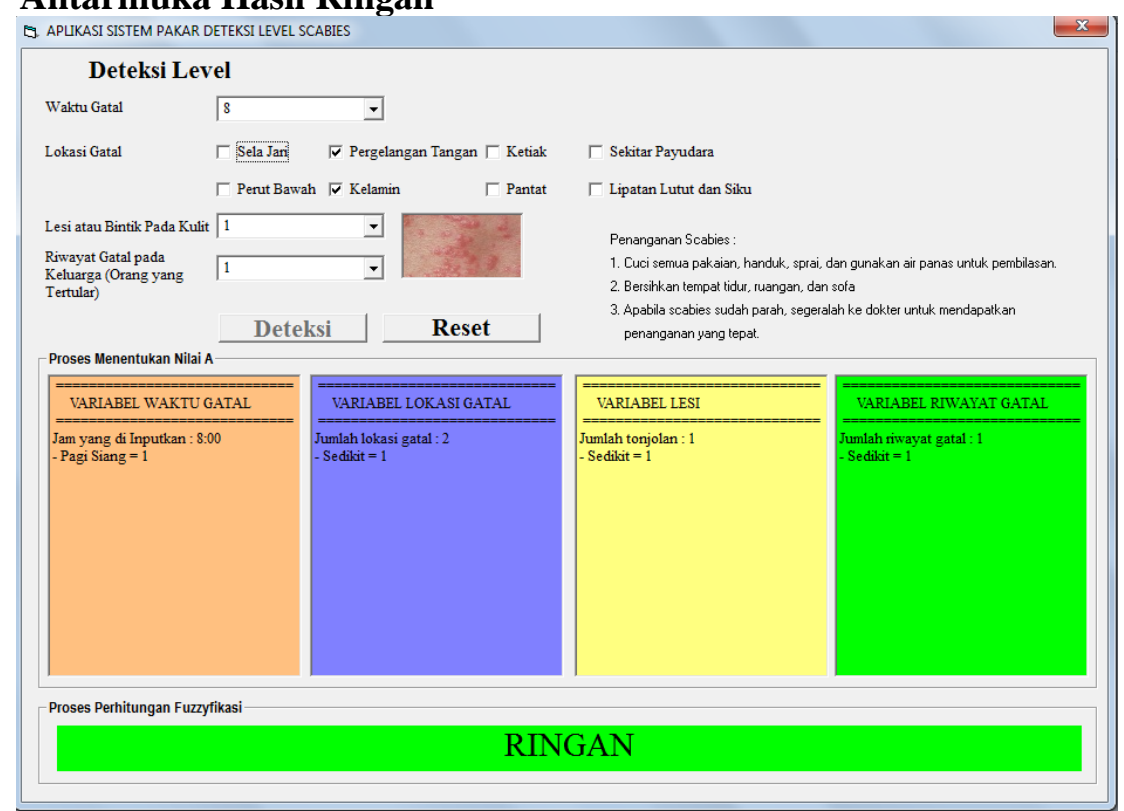

\section{Gambar 7. Hasil Ringan}

Gambar di atas merupakan hasil perhitungan sistem yang menunjukkan scabies ringan.

\subsubsection{Antarmuka Hasil Berat}

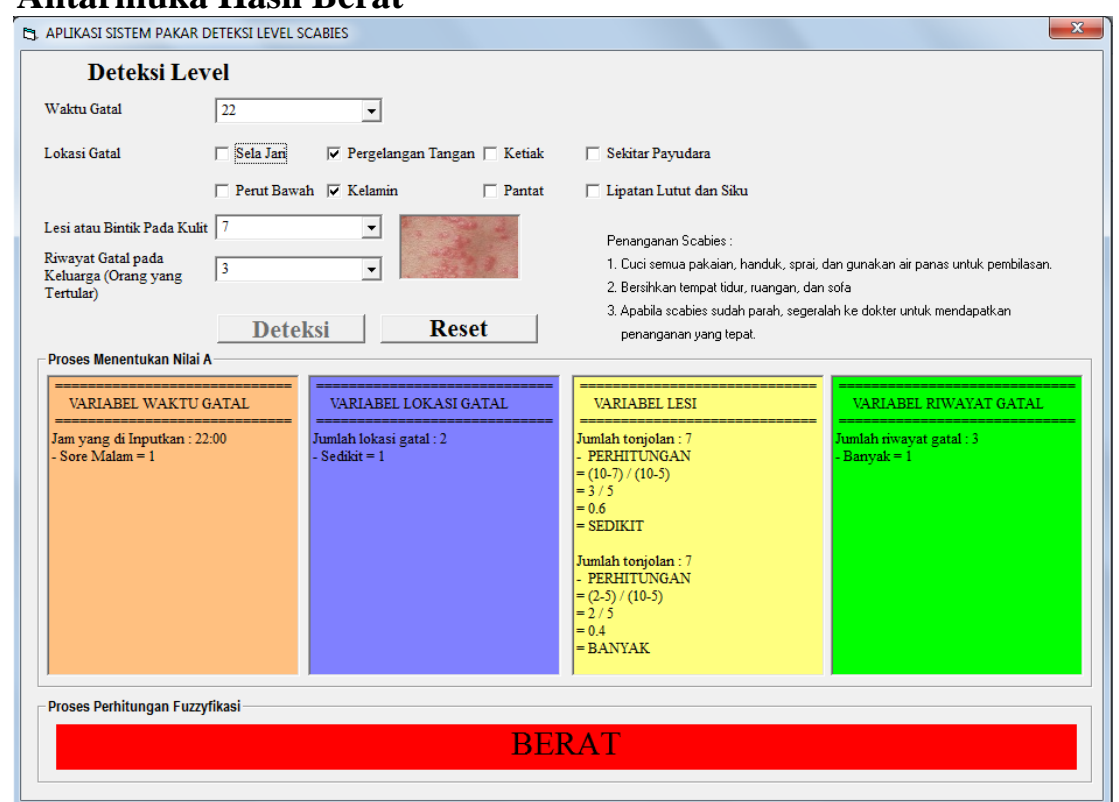

Gambar 8. Hasil Berat

Gambar di atas merupakan hasil perhitungan sistem yang menunjukkan scabies berat.

\section{KESIMPULAN}

Berdasarkan analisisyang telah dilakukan, Penggunaan metode fuzzy tsukamoto dapat mendiagnosa level penyakit scabies dengan digunakannya variabel - variabel dari gejala penyakit yang dialami oleh pasien. Penentuan level penyakit scabies dihasilkan dari pengisian data pada kriteria tersebut. sistem pakar ini juga dapat digunakan untuk alat bantu sementara dalam mendiagnosa level penyakit scabies. 


\section{SARAN}

Karena keterbatasan pengetahuan, maka perlu dilakukan perbaikan dan diusulkan beberapa saran yaitu:

1. Perbaikan dan pengembangan secara luas dengan metode yang lain diharapkan dapat menjadi perbandingan antara metode fuzzy tsukamoto dan yang lainnya.

2. Pengembangan sistem diharapkan dapat meningkatkan akurasi dari sistem ini dengan mengumpulkan data penyakit scabies dari beberapa dokter atau ahli sehingga dalam menentukan variabel dan rule akan menjadi lebih valid.

3. Pengembangan dapat dilakukan dengan menambahkan fitur yang belum ada dan diharapkan akan mempermudah user dalam penggunaannya.

\section{DAFTAR PUSTAKA}

[1]

"Penyakit Kulit." [Online]. Available: https://www.academia.edu/6712635/Penyakit_kulit_adalah_penyakit_infeksi_yang_umum. [Accessed: 03-Apr-2016].

[2] "Penyakit Scabies." [Online]. Available: http://mediskus.com/penyakit/scabies-kudis-gudik. [Accessed: 03-Apr-2016].

[3] Y. I. Setyaningrum, "Seminar Nasional Pendidikan Biologi FKIP UNS 2010237 Seminar Nasional Pendidikan Biologi FKIP UNS 2010," pp. 237-243, 2010.

[4] "Sistem Pakar." [Online]. Available: https://www.prezi.com/m/nk800gwcc8z7/sistem-pakar/. [Accessed: 03-Apr-2016].

[5] Sutojo, E. Mulyanto, and V. Suhartono, Kecerdasan Buatan. Semarang: Andi Offset, 2011.

[6] T. Murti, L. A. Abdillah, and M. Sobri, "Sistem Penunjang Keputusan Kelayakan Pemberian Pinjaman Dengan Metode Fuzzy Tsukamoto," pp. 252-256, 2015.

[7] Maryaningsih, Siswanto, and Mesterjon, "Metode Logika Fuzzy Tsukamoto Dalam Sistem Pengambilan Keputusan Penerimaan Beasiswa," vol. 9, no. 1, 2013.

[8] R. Amelia, "Implementasi Metode Fuzzy Tsukamoto Pada Penentuan Harga Jual Barang Dalam Konsep Fuzzy Logic,” pp. 104-109, 2013.

[9] A. Saepullah and R. S. Wahono, "Comparative Analysis of Mamdani , Sugeno And Tsukamoto Method of Fuzzy Inference System for Air Conditioner Energy Saving," vol. 1, no. 2, pp. 143-147, 2015.

[10] "Pengertian Fuzzy Logic." [Online]. Available: http://www.temukanpengertian.com/2013/08/pengertian-fuzzy-logic.html?m=1. [Accessed: 03-Apr-2016]. 